\title{
Physicochemical and sensory changes in aged sugarcane spirit submitted to filtering with activated carbon filter
}

\author{
Alterações físico-químicas e sensoriais de cachaças envelhecidas submetidas à filtragem com carvão ativado
}

Felipe Cimino DUARTE ${ }^{1}$, Maria das Graças CARDOSO ${ }^{2 *}$, Ana Carla Marques PINHEIRO ${ }^{1}$, Wilder Douglas SANTIAGO ${ }^{2}$, Leonardo Luna de CARVALHO ${ }^{1}$

\begin{abstract}
Sugarcane spirit is a drink considered as a national symbol of Brazil. It is produced by large producers and by about 30 thousand small and medium home-distilling producers dispersed throughout the country. The copper originating from the home-distillers can become a serious problem since at high concentrations in beverages it may cause serious human health problems. Therefore, the objective of this study was to investigate the influence of the activated carbon used in commercial filters on the physicochemical and sensory characteristics of aged sugarcane spirit. Analyses of copper, dry extract, alcoholic degree, higher alcohols, volatile acids, aldehydes, esters, furfural, and methanol were performed. The sensory evaluation was performed by seven selected trained judges, who analyzed the yellow color, woody aroma and flavor, and intensity of alcoholic aroma and flavor of the cane spirit before and after the filtration process. The sensory tests were carried out using a $9 \mathrm{~cm}$ non-structured intensity scale. A reduction was observed in all compounds analyzed physicochemically, except for the esters, which increased after filtration. This increase is probably due to the esterification of the alcohols and acids present. According to the sensory results obtained, a reduction was observed in the intensity of the yellow color, aroma, and wood flavor characteristics, the major characteristics of the aging process.
\end{abstract}

Keywords: sugarcane spirit; filtering; carbon; sensory and physicochemical analysis.

\section{Resumo}

A cachaça é uma bebida considerada símbolo nacional, sendo produzida por grandes produtores e por cerca de 30 mil pequenos e médios produtores de alambiques artesanais espalhados por todo o País. O cobre oriundo dos destiladores dos alambiques artesanais pode tornar-se um grande problema, pois esse metal, em grandes concentrações na bebida, acarreta sérios problemas à saúde humana. Desta forma, objetivou-se estudar a influência da filtragem em carvão utilizado nos filtros comerciais sobre as características físico-químicas e sensoriais de aguardentes de cana envelhecidas. Realizaram-se as análises de cobre, extrato seco, grau alcoólico, álcoois superiores, acidez volátil, aldeídos, ésteres, furfural e metanol. A avaliação sensorial foi realizada com equipe de provadores selecionados e treinados, os quais analisaram a intensidade da cor amarela, sabor e aroma de madeira e sabor e aroma alcoólico das cachaças antes e após a filtragem. Os testes sensoriais foram realizados por meio de escala de intensidade, não estruturada e de $9 \mathrm{~cm}$. Observou-se uma redução em todos os compostos físico-químicos analisados, exceto ésteres, que aumentaram nas cachaças após a filtragem. Provavelmente este aumento ocorreu devido à esterificação dos álcoois e ácidos presentes. De acordo com os resultados sensoriais obtidos, observou-se redução na intensidade das características cor amarela, aroma e sabor de madeira, principais características adquiridas no processo de envelhecimento.

Palavras-chave: aguardentes de cana; filtragem; carvão; análises sensorial e físico-química.

\section{Introduction}

Sugarcane spirit is a genuine Brazilian drink; it reaches 1.5 billion liters annually representing $87 \%$ of the national production of alcoholic drinks moving US \$1 billion a year in the internal market. It is produced by large producers, holders of major brands that dominate the market, and by about 30 thousand small and medium home-distilling producers throughout the country (ALCARDE; SOUZA; BELLUCO, 2010; INSTITUTO..., 2008).

In the state of Minas Gerais, the largest producer of the homemade drink distilled in copper pot stills, there are
8,500 producers, from which 600 brands are registered with the Ministry of Agriculture, Livestock and Provision (Mapa) generating about 240 thousand direct and indirect jobs. (SEBRAE, 2008).

Sugarcane spirit is part of the class of fermented-distilled alcoholic drinks, and it stands out due to the presence of secondary components that form a characteristic "bouquet" for each drink. At the end of the distillation process, containers, in which there are physicochemical changes that improve the sensory characteristics of the drink incorporating aromas

Received $8 / 4 / 2010$

Accepted 28/2/2012 (004783)

${ }^{1}$ Departamento de Ciência dos Alimentos, Universidade Federal de Lavras - UFLA, CP 3037, CEP 37200-000, Lavras, MG, Brasil

2 Departamento de Química, Universidade Federal de Lavras - UFLA, CP 3037, CEP 37200-000, Lavras, MG, Brasil, e-mail: mcardoso@dqi.ufla.br

${ }^{*}$ Corresponding author 
according to the absorption of the components of the wood used in the aging. The transformation from the originally strong product into a product with softer and desirable characteristics also occurs, increasing its acceptability by the consumer (CARDELlO; FARIA, 2000). Miranda, Hoii and Alcarde (2006) state that in such process, several chemical reactions that provide the incorporation of compounds originating from the wood of the containers occur, as well as reactions among some compounds present in the drink originating from pre-aging stages.

The improvement of the sensory quality and meeting the requirements related to some chemical components present in sugarcane spirits are crucial for the drink to meet the international standards and be accepted by the foreign market promoting the opening and maintenance of the export market.

Quality has been the key word for the producers of sugarcane spirits, rum, and liquor. This parameter is evaluated through the chemical composition of the drink, for which there are national regulations that are not always respected, but they are not more relevant than the sensory quality of the drink which contributes to guarantee success in the market.

Among the sugarcane spirit quality parameters, the amount of copper in the drink has been a concern of the Ministry of Agriculture, Livestock and Provisioning (MAPA). Originating during the distillation process, the copper found in the drink should not exceed the value of $5 \mathrm{mg} \cdot \mathrm{L}^{-1}$ established by MAPA (BRASIL, 2005). However, this limit value has not been observed by the large majority of the producers, which hinders the export of the product.

The home sugarcane spirit production results in some peculiarities in the final product. Works by Faria and Lourenço (1990) argue that the copper used in the distillers catalyzes some reactions removing some unpleasant odors characteristic of sugarcane spirits produced in stills made from other materials, such as stainless steel and others. As a consequence of the use of these distillers, one of the biggest problems found in the home sugarcane spirit production has been the excess of copper (VILELA et al., 2007).

Several producers use different materials to remove the excess copper and, among the most common, are activated carbon and ion exchange resins. Data of Lima et al. (2006) show that resins are the best option to remove the excess copper influencing lightly the concentration of the congeners.

Although filtering sugarcane spirits using resin or activated carbon filters is a common technique among the producers seeking to remove the excess copper, studies on the influence of this process on the sensory quality of the product are still lacking.

As a result, the present study aimed to evaluate the differences in the physicochemical composition and sensory quality of sugarcane spirits aged before and after the filtering with commercial activated carbon filter.

\section{Materials and methods}

\subsection{Materials}

Two samples of sugarcane spirits produced by home-distilling producers in southern Minas Gerais were used. They were aged wooden oak containers of $250 \mathrm{~L}$ (Quercus alba) for 3 years (L3) and of 50,000 L for 4 years (L9). After the filtering, the samples obtained were denominated F3 and F9 from the filtering of L3 and L9, respectively. The sensory evaluation was performed using a two-by-two comparison: L3 with F3, and L9 with F9.

\subsection{Methods}

\section{Filtering}

A chromatography column of $2.5 \mathrm{~cm}$ of radius and $70.0 \mathrm{~cm}$ of length was used in the filtering process. The activated carbon was macerated to pack the chromatography column to a packing volume of $200 \mathrm{~cm}^{3}$. The experimental practice was conducted at the Sugarcane Spirit Physicochemical Analyses Laboratory (LAFQA)/DQI-Federal University of Lavras (Lavras - MG)

\section{Physicochemical analyses}

The following physicochemical analyses were performed in triplicate: copper, dry extract, alcoholic degree, higher alcohols, volatile acidity, aldehydes, esters, furfural, and methanol. These analyses were performed at the Laboratory of Physicochemical Analyses of Liquor (LAFQA) / DQI-Federal University of Lavras (Lavras - MG) adopting the Methods of Analyses of Fermented and Distilled non-Alcoholic Drinks and Vinegar established by the Normative Instruction n. 13 of the MAPA (BRASIL, 2005).

\section{Sensory analysis}

The sensory tests were carried out at the Sensory Analysis Laboratory of the Food Science Department (DCA) of the Federal University of Lavras-UFLA, in individual cabins with controlled illumination and room temperature.

Due to the ingestion of alcoholic drinks by human beings, the project was submitted and approved by the of Research Ethics Committee of the Vale do Rio Doce University -Unicor/ Três Corações/MG, Certificate of Presentation for Ethics Assessment (CAAE) number 0015.0.380.000-08.

The sensory characteristics of the samples were evaluated using non-structured $9 \mathrm{~cm}$ intensity scales, as described by Stone and Sidel (1993) for the development of the Quantitative Descriptive Analysis $\left(\mathrm{QDA}^{\circ}\right)$ with selected and trained judges.

For the recruitment and pre-selection of the judges, invitations were delivered by hand or sent out by e-mail to 60 people. Interested candidates who were willing to participate in the research filled out a Consent and Clarification form. Only thirty two candidates met the prerequisites, for example how to ingest sugarcane spirits and having time available to participate in the analyses and meetings. 
A pre-selection of judges was conducted using the Triangular Test, following the method of the American Society for Testing and Materials - ASTM (1981), using an industrial sugarcane spirit and an aged sugarcane spirit for one year. Of the 32 pre-selected judges, only 12 obtained scores above 5 , the minimum correct responses $(62.5 \%)$ required in 8 sessions, and those were selected to participate in the test.

The definition of the characteristics to be analyzed and judges' training was based on studies of Quantitative Descriptive Analysis-QDA ${ }^{\circ}$ with sugarcane liquors conducted by Dornelles, Rodrigues and Garruti (2009); Yokota et al. (2003); Carvalho and Minim (2000); Cardello and Faria $(2000,1998)$. Therefore, the following characteristics were defined: yellow color, alcohol aroma, woody aroma, alcohol flavor, and woody flavor, since these are the most important characteristics of aged sugarcane spirits in wood containers.

After the definition of these characteristics, a table was drawn with the respective definitions and references (weak/ none and strong) for each one. (Table 1).

Later, an evaluation chart was drawn containing the $9 \mathrm{~cm}$ non- structured linear scale anchored with the term "weak or none" on its left end, and with the term "strong" at its right end for each characteristic to be evaluated.

After defining the characteristics, the pre-selected judges were trained following the recommendations of Stone and Sidel (1993).

In the training sessions, the candidates should try to define the references (weak or none and strong) according to the color, alcohol aroma, woody aroma, alcohol flavor, and woody flavor.

Those references were assessed by the candidates in several sessions until they remained in their memories.

Next, the judges evaluated three types of sugarcane spirit samples, an industrial one (non-aged) and two homemade (one aged for 2 years in oak and another aged for 2 years in oak and 2 years in cinnamon laurel), in four repetitions using the descriptive test chart.
The judges received samples of approximately $5 \mathrm{~mL}$, at a temperature of $22^{\circ} \mathrm{C}$, served in glasses $(50 \mathrm{~mL})$ codified with 3 digit numbers with a glass of water and a cracker to eliminate drink residues in the mouth.

For the yellow color intensity analysis, the samples were served in booths with fluorescent white light. For the analysis of characteristics associated to flavor and aroma, the samples were served in booths with red lighting to mask the color differences and control the inherent psychological effect. The samples were served according to a balanced presentation order (WAKELING; MACFIE, 1995) using the monadic presentation technique.

After these stages, variance analysis was carried out (ANOVA) with two variation sources (sample and repetition) for each attribute and for each judge. The values for $\mathrm{F}_{\text {sample }}$ and $\mathrm{F}_{\text {repetition }}$ for each judge were then obtained aiming to evaluate their performance.

Only the judges who obtained significant $\left[\mathrm{p}(\mathrm{F})_{\text {sample }}<0.50\right]$ $\mathrm{F}_{\text {sample }}$ values and not significant $\left[\mathrm{p}(\mathrm{F})_{\text {repetition }}>0.05\right]$ were selected.

In the definitive test (intensity scale) the judges analyzed samples L3 with F3 and L9 with F9 separately. Each pair was evaluated in four repetitions. The test conditions (sample volume, conduction local, and presentation order) were the same as previously described.

The data were analyzed through ANOVA having sample, judges, and the interaction among the factors as sources of variation aiming to evaluate the existence or not of significant differences among the samples in the different analyzed characteristics and also to verify the performance of the judges in the final test $[\mathrm{p}(\mathrm{F})$ taster $>0.05$ and $\mathrm{p}(\mathrm{F})$ interaction $>0.05]$, also following recommendations of Stone and Sidel (1993).

\subsection{Statistical analysis}

Due to the analysis of the samples in pairs, the data of the physicochemical analyses and those of the descriptive and quantitative analysis $\left(\mathrm{ADQ}^{\circ}\right)$ were evaluated using the $\mathrm{F}$ test and variance analysis. All statistical analyses were performed using the SISVAR statistical software (FERREIRA, 2003).

Table 1. Definitions and references of the characteristics analyzed by the judges.

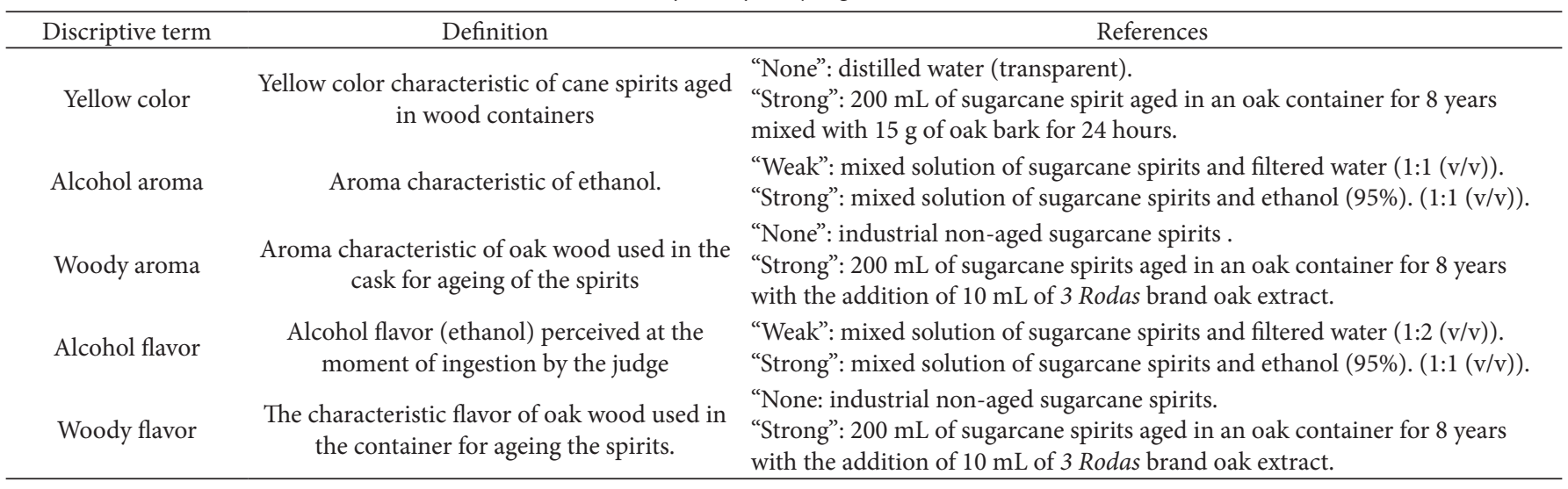




\section{Results and discussion}

\subsection{Physicochemical}

The results obtained for the physicochemical analyses of the sugarcane spirits, before and after filtering, are presented in Table 2.

After performing the physicochemical analyses of the drinks, it was verified that the samples before and after the filtering met the Identity and Quality Standards (PIQ), established by the current law, for all of the attributes, except for furfural that presented a maximum limit up to five times higher in sample L9. According to Egorov and Rodopulo (1994), mentioned by Miranda, Hoii and Alcarde (2006), furfural concentration, a compound that can originate from the degradation of the wood pentose, tends to increase with the maturation of the distillate, which can explain the high values found for this compound before the filtering. In the present study, it was verified that the filtering process was efficient in the removal of this compound reducing it to levels below those established by the legislation.

Before the filtering, it was verified that the copper concentrations in the samples were below those required for exporting sugarcane; this metal reduced significantly after the filtering. Lima et al. (2006), investigating the influence of activated carbon at the concentrations of 12 and 26 g. $\mathrm{L}^{-1}$ in sugarcane spirits containing $9 \mathrm{mg}$ copper $\mathrm{L}^{-1}$, verified that there was a reduction in the metal levels of 3.5 and $0.2 \mathrm{mg} . \mathrm{L}^{-1}$, respectively.

After filtering, a small decrease was observed in the alcohol content of the samples, which can be explained by the retention of alcohol in the charcoal filter or by its possible oxidation into acetic aldehyde and, later, acetic acid, or even by the evaporation of the ethanol during this procedure. The results of this study are similar to those found by Miranda et al. (2008).

The decrease in the volatile acidity in sample L9 can be explained by the interaction between the carboxylic acids and the charcoal filter used, in which the acids can be retained. These acids are volatile; therefore, they have a short carbon chain, such as the acetic acid, which is its main constituent. The fast decrease in this component found in this study was lower than that found by Lima et al. (2006) using activated carbon at various concentrations.

The results obtained for the aldehydes showed a decrease in their concentration after the filtering of samples L3 and L9, explained by their removal by the charcoal filter employed, or by the oxidation of the aldehydes into the respective carboxylic acids, or even by a possible partial loss of the aldehydes due to evaporation during the filtration process. Comparing the results obtained with those mentioned by Lima et al. (2006), it can be concluded that the results obtained are within the expected range.

An increase in the esters was verified for sample L1 after the filtering of the sugarcane spirits. This fact is probably due to the esterification reaction that takes place between the alcohols and the carboxylic acids forming the esters. The presence of a high amount of carboxylic acids in the medium favors the formation of an even larger amount of esters (CARDOSO, 2006).

Methanol was not detected in the samples before and after the filtering. Similar results were also verified by Lima et al. (2006), who found very low initial and final concentration after the filtering; therefore, it was not possible to discuss the effect of the activated carbon on the methanol.

\subsection{Training and selection of judges}

After obtaining the training data, analysis of variance (ANOVA) was used to evaluate the performance of each judge through the values: $\mathrm{P}_{\text {sample }}<0.50$ and $\mathrm{P}_{\text {repetition }}>0.05$, which are presented in Tables 3 and 4, respectively.

Hence, of the twelve pre-selected judges in the training, only seven were selected for the definitive test.

Stone and Sidel (1993) suggest between 10 and 12 judges for the final analysis; however, Zook and Pearce (1988) and Sidel, Stone and Blommquist (1981) report the use from 6 to 8 judges for descriptive sensory evaluation, and Yokota (2005) used the results of 8 judges. The seven judges selected presented satisfactory performance in discriminating the samples according to the different attributes evaluated (Table 3), as well as in relation to repeatability (Table 4).

Table 2. Results of physical and chemical analysis before and after filtration with activated charcoal.

\begin{tabular}{|c|c|c|c|c|c|c|}
\hline Samples & $\begin{array}{c}\text { Dry extract }^{*} \\
\text { (Before filtration) }\end{array}$ & $\begin{array}{c}\text { Dry extract* } \\
\text { (After filtration) }\end{array}$ & $\begin{array}{c}\text { Ethanol } \\
\text { concentration }^{* *} \\
\text { (Before filtration }\end{array}$ & $\begin{array}{c}\text { Ethanol } \\
\text { concentration }{ }^{\star *} \\
\text { (After filtration) }\end{array}$ & $\begin{array}{l}\text { Higher alcohols } \\
\text { (Before filtration) }\end{array}$ & $\begin{array}{l}\text { Higher alcohols }{ }^{* * *} \\
\text { (After filtration) }\end{array}$ \\
\hline L3 & $0.21^{\mathrm{a}}$ & $0.21^{\mathrm{a}}$ & $46.60^{\mathrm{a}}$ & $46.29^{b}$ & $225.34^{\mathrm{a}}$ & $210.17^{\mathrm{a}}$ \\
\hline L9 & $0.39^{\mathrm{a}}$ & $0.33^{\mathrm{a}}$ & $51.70^{\mathrm{a}}$ & $51.14^{\mathrm{b}}$ & $221.64^{\mathrm{a}}$ & $207.11^{\mathrm{a}}$ \\
\hline Samples & $\begin{array}{l}\text { Volatile acidity } \\
\text { (Before filtration) }\end{array}$ & $\begin{array}{l}\text { Volatile acidity } \\
\text { (After filtration) }\end{array}$ & $\begin{array}{c}\text { Aldehydes }{ }^{* * *} \\
\text { (Before filtration) }\end{array}$ & $\begin{array}{c}\text { Aldehyes } \\
\text { (After filtration) }\end{array}$ & $\begin{array}{c}\text { Esters }^{\star * \star} \\
\text { (Before filtration) }\end{array}$ & $\begin{array}{c}\text { Esters }{ }^{\star * *} \\
\text { (After filtration) }\end{array}$ \\
\hline L3 & $37.83^{\mathrm{a}}$ & $33.49^{\mathrm{b}}$ & $15.46^{\mathrm{a}}$ & $12.44^{\mathrm{b}}$ & $37.86^{\mathrm{a}}$ & $32.09^{\mathrm{a}}$ \\
\hline L9 & $75.44^{\mathrm{a}}$ & $69.48^{\mathrm{b}}$ & $21.35^{\mathrm{a}}$ & $20.43^{\mathrm{b}}$ & $56.69^{a}$ & $60.25^{\mathrm{b}}$ \\
\hline Samples & $\begin{array}{c}\text { Copper } \\
\text { (Before filtration) }\end{array}$ & \multicolumn{2}{|c|}{$\begin{array}{c}\text { Copper } \\
\text { (After filtration) }\end{array}$} & \multicolumn{2}{|c|}{$\begin{array}{c}\text { Furfural } \\
\text { (Before filtration) }\end{array}$} & $\begin{array}{c}\text { Furfural } \\
\text { (After filtration) }\end{array}$ \\
\hline L3 & $0.73^{\mathrm{a}}$ & \multicolumn{2}{|c|}{$0.00^{\mathrm{b}}$} & \multicolumn{2}{|c|}{$10.38^{\mathrm{a}}$} & $2.34^{\mathrm{b}}$ \\
\hline L9 & $0.72^{\mathrm{a}}$ & \multicolumn{2}{|c|}{$0.25^{\mathrm{b}}$} & \multicolumn{2}{|c|}{$25.62^{\mathrm{a}}$} & $2.04^{\mathrm{b}}$ \\
\hline
\end{tabular}

Means followed by the same letter in the row do not differ significantly by the Tukey test at $\mathrm{p}<0.5 .\left({ }^{\star} \mathrm{mg} \cdot \mathrm{L}^{-1} ;{ }^{\star *} \% \mathrm{v} / \mathrm{v} ;{ }^{* * *} \mathrm{mg} .100 \mathrm{~mL}{ }^{-1}\right.$ of anhydrous ethanol). 
These results proved the ability of the judges to participate in the definitive test with aged samples (L3 and L9) comparing them to the filtered samples (F3 and F9), respectively.

\subsection{Definitive test: intensity scale}

After training and selection, the seven selected judges participated in the definitive sensory tests. They evaluated samples L3 and F3 together and samples L9 and F9 separately. After obtaining the data, ANOVA was used to evaluate the differences among the samples and the performance of the judges in the final test including the samples, the judges, and the interaction among them (Table 5).

The probability values of $\mathrm{F}$ for the judges were not significant for all attributes analyzed in the L3-F3 sample evaluation showing that the judges used the same proportions of the scale for a same sample. That difference was observed for the attributes color and alcohol aroma in the samples L9-F9. However, according to Stone and Sidel (1993), this is a common finding in sensory tests. The interaction between the sample and the judge was not shown to be significant for any of the analyzed characteristics demonstrating homogeneity and consensus among the responses of the seven judges.

It was observed, for analysis of L3 - F3 samples, as well as for L9 - F9 samples, a significant difference $(p<0.01)$ in most of the evaluated attributes, with the exception of the alcohol flavor (Table 5).

The comparative statistical results of the average values of the characteristics evaluated for samples L3 with F3 and L9 with F9, respectively, are presented in Table 6. These results show that the filtering caused a significant and accentuated reduction in the intensity of yellow color, aroma and woody flavor, and alcohol aroma after the filtering. The decrease in the color, aroma, and woody flavor can be explained by the decrease in furfural, which is one of the various phenolic compounds that are characteristic of aged drinks.

The main compounds extracted from the wood of the container by the distillates are volatile oils, non-volatile phenolic compounds, glycerol, and other compounds responsible for the color of the drink (CARDELLO; FARIA, 2000).

Table 3. Performance of the seven judges in discriminating samples $\left(\mathrm{P}(\mathrm{F})_{\text {samples }}<0.05\right)$.

\begin{tabular}{cccccc}
\hline \multicolumn{7}{c}{ Attribute } \\
\hline Taster & Color & Woody aroma & Alcoholic aroma & Alcoholic flavor & Woody flavor \\
\hline 1 & 0.0010 & 0.0056 & 0.0060 & 0.0024 & 0.0012 \\
2 & 0 & 0.0001 & 0.0007 & 0.1785 & 0.0004 \\
3 & 0.0006 & 0.0004 & 0.0005 & 0.4023 & 0.0001 \\
4 & 0.0009 & 0.0020 & 0.0001 & 0.0034 & 0.0009 \\
5 & 0 & 0.0006 & 0.0001 & 0.0001 & 0.0003 \\
6 & 0 & 0 & 0.0096 & 0.0007 & 0.0003 \\
\hline
\end{tabular}

Table 4. Performance of the seven judges per repetition ( $\mathrm{pr}>0.05$ among samples).

\begin{tabular}{cccccc}
\hline \multicolumn{5}{c}{ Attribute } \\
\hline Taster & Color & Woody aroma & Alcoholic aroma & Alcoholic flavor & Woody flavor \\
\hline 1 & 0.0667 & 0.5534 & 0.5610 & 0.0591 & 0.6676 \\
2 & 0.4547 & 0.6246 & 0.2240 & 0.9735 & 0.7265 \\
3 & 0.3358 & 0.5826 & 0.9757 & 0.2212 & 0.1169 \\
4 & 0.1854 & 0.3420 & 0.3168 & 0.7941 & 0.3731 \\
5 & 0.4547 & 0.5894 & 0.0508 & 0.8022 & 0.4547 \\
6 & 0.4547 & 0.1889 & 0.4883 & 0.1060 & 0.9522 \\
\hline
\end{tabular}

Table 5. Probability values of F for samples L3-F3 and L9-F9, judge, and interaction of the sample with the judge.

\begin{tabular}{|c|c|c|c|c|c|c|}
\hline \multirow{2}{*}{ Attributes } & \multicolumn{3}{|c|}{ L3-F3 } & \multicolumn{3}{|c|}{ L9-F9 } \\
\hline & Sample & Taster & Sample $\times$ Taster & Sample & Taster & Sample $\times$ Taster \\
\hline Color & $0^{*}$ & $0.0528 \mathrm{~ns}$ & $0.3088 \mathrm{~ns}$ & $0^{*}$ & $0.0039^{*}$ & $0.0768 \mathrm{~ns}$ \\
\hline Woody aroma & $0^{*}$ & $0.6519 \mathrm{~ns}$ & $0.3042 \mathrm{~ns}$ & $0^{*}$ & $0.0768 \mathrm{~ns}$ & $0.2520 \mathrm{~ns}$ \\
\hline Alcoholic aroma & $0^{*}$ & $0.2005 \mathrm{~ns}$ & $0.0545 \mathrm{~ns}$ & $0.0451 \mathrm{~ns}$ & $0.0001^{\star}$ & $0.6163 \mathrm{~ns}$ \\
\hline Woody aroma & $0^{*}$ & $0.0679 \mathrm{~ns}$ & $0.1137 \mathrm{~ns}$ & $0.7083 \mathrm{~ns}$ & $0.6234 \mathrm{~ns}$ & $0.0797 \mathrm{~ns}$ \\
\hline Alcoholic aroma & $0.1058 \mathrm{~ns}$ & $0.2360 \mathrm{~ns}$ & $0.1297 \mathrm{~ns}$ & $0^{*}$ & $0.2390 \mathrm{~ns}$ & $0.1826 \mathrm{~ns}$ \\
\hline
\end{tabular}

${ }^{*}$ Significant at $5 \%$, ns $=$ not significant. 
Table 6. Average judge scores for the attributes color, woody aroma, alcohol aroma, woody flavor, and alcohol flavor of sugarcane spirits aged in oak containers before and after filtering.

\begin{tabular}{cccccc}
\hline Samples & Color scores & Woody aroma scores & Alcohol aroma scores & Woody flavor scores & Alcohol flavor scores \\
\hline F3 & $0.57^{\mathrm{a}}$ & $1.04^{\mathrm{a}}$ & $1.14^{\mathrm{a}}$ & $0.71^{\mathrm{a}}$ & $6.85^{\mathrm{a}}$ \\
L3 & $4.90^{\mathrm{b}}$ & $6.61^{\mathrm{b}}$ & $6.71^{\mathrm{b}}$ & $4.67^{\mathrm{b}}$ & $7.28^{\mathrm{a}}$ \\
F9 & $1.43^{\mathrm{a}}$ & $2,62^{\mathrm{a}}$ & $6.54^{\mathrm{a}}$ & $2.47^{\mathrm{a}}$ & $7.47^{\mathrm{a}}$ \\
L9 & $7.19^{\mathrm{b}}$ & $7.76^{\mathrm{b}}$ & $6.99^{\mathrm{b}}$ & $6.85^{\mathrm{b}}$ & $7.38^{\mathrm{a}}$ \\
\hline
\end{tabular}

Means with the same letter in the column of each component do not differ significantly by Tukey test at $\mathrm{p}<0.5$.

Lima et al. (2006), investigating the use of carbon and resin for copper removal in non-aged sugarcane spirits, states that during the copper removal process other products can also be adsorbed by the carbon and be removed from the sugarcane spirits. These same authors concluded that activated carbon should be used with caution, so that the organic compounds responsible for the aroma and flavor of the sugarcane spirits are not removed in amounts that devalue the drink.

Probably, many of these compounds were removed from the sugarcane spirits during the filtering process with a commercial carbon filter promoting a decrease in some desired characteristics of aged sugarcane spirits (yellow color, woody aroma, and flavor).

Cardello and Faria (1998), analyzing the sensory profile of aged sugarcane spirits, described that the attributes that most characterize these drinks were initial woody flavor, vanilla aroma, woody aroma, woody aftertaste, yellow coloration, acidity, and astringency.

Significant differences were not observed in the alcohol flavor in samples L3-F3 and L9-F9 (Table 6), which is probably due to the high alcohol content of the drinks, approximately 47 and $57 \%$ v/v, respectively, which might have hindered the differentiation of this characteristic by the judges. In addition, in the alcohol content quantification analyses (data not shown), there was no significant difference among non-filtered and filtered sugarcane spirits.

\section{Conclusions}

The filtration of aged sugarcane spirits with an activated charcoal filter proved efficient in reducing the copper to low levels, within those established by the national legislation, and also in the reduction of furfural. However, an increase in the esters was observed, possibly due to the interaction of the drink with the filter medium.

The filtering of sugarcane spirits aged in oak containers using commercial activated carbon filter causes reduction in the intensity of the sensory attributes of the yellow color, aroma, and woody flavor.

The use of this procedure is not viable for sugarcane spirits after aging due to loss of essential characteristics of the drink during this process.

Although the filtering reduced components such as copper and furfural in the aged sugarcane spirits, it caused a reduction in distinct sensory characteristics of the product.

\section{Acknowledgements}

The authors are grateful for the financial support provided by The National Council for Scientific and Technological Development (CNPq) and The State of Minas Gerais Research Foundation (FAPEMIG).

\section{References}

ALCARDE, A. R.; SOUZA, P. A.; BELLUCO, A. E. S. Aspects of the chemical composition and sensorial acceptance of sugar cane spirit aged in casks of different types of woods. Ciências e Tecnologia de Alimentos, v. 30, p. 226-232, 2010. Suplemento 1.

AMERICAN SOCIETY FOR TESTING AND MATERIALS - ASTM. Guidelines for the selection and training of sensory panel members. Philadelphia: ASTM, 1981. 35 p.

BRASIL. Ministério da Agricultura, Pecuária e Abastecimento - MAPA. Instrução normativa $n^{\circ} 13$, de 29 de junho de 2005. Aprova o Regulamento Técnico para Fixação dos Padrões de Identidade e Qualidade para Aguardente de Cana e para Cachaça. Diário Oficial da República Federativa do Brasil, Brasília, DF, 30 jun. 2005.

CARDELLO, H. M. A. B.; FARIA, J. B., Análise descritiva quantitativa da aguardente de cana durante o envelhecimento em tonel de carvalho (Quercus alba L.). Ciências e Tecnologia de Alimentos, v. 18, n. 2, 1998.

CARDELLO, H. M. A. B.; FARIA, J. B., Perfil Sensorial e características Físico-Químicas de Aguardentes Comerciais Brasileiras Envelhecidas e Sem Envelhecer. Brazilian Journal of Food Technology, v. 3, p. 31-40, 2000.

CARDOSO, M. G. et al. Produção de aguardente de cana de açúcar. Lavras: Editora UFLA, 2006. 444 p.

CARVAlHO, S. A.; MINIM, V. P. R. Perfil Sensorial de Aguardente de Cana de açúcar Envelhecida em Tonéis de Diferentes Tipos de Madeira. In: CONGRESSO BRASILEIRO DE CIÊNCIA E TECNOLOGIA DE ALIMENTOS, 17., 2000, Fortaleza. Anais... Fortaleza, 2000. v. 1, p. 3.12.

DORNELLES, A. S.; RODRIGUES, S.; GARRUTI, D. S. Aceitação e perfil sensorial das cachaças produzidas com Kefir e Saccharomyces cerevisae. Ciências e Tecnologia de Alimentos, v. 29, n. 3, p. 518-522, 2009.

FARIA, J. B.; LOURENCO, E. J. A Influência do cobre na composição das aguardentes de cana (Saccharum officinarum L.). Alimentos e Nutrição, v. 2, p. 93-100, 1990.

FERREIRA, D. F. SISVAR. versão 4.6 (Bluild 61). Lavras: UFLA/DEX, 2003. Software.

INSTITUTO BRASILEIRO DA CACHAÇA - IBRAC. Exportação da cachaça aumenta em 2008. Portal do Agronegócio, 2008. Acesso em: 27 out. 2008. <http://www.portaldoagronegocio.com.br/ conteudo.php?id=24437>. 
LIMA, A. J. B. et al. Emprego do carvão ativado para remoção de cobre em cachaça. Química Nova, v. 29, n. 2, p. 247-250, 2006.

MIRANDA, M. B.; HOII, J.; ALCARDE, A. R. Estudo do efeito da irradiação Gamma $\left({ }^{60} \mathrm{CO}\right)$ na qualidade da cachaça e no tonel de envelhecimento. Ciências e Tecnologia de Alimentos, v. 26, n. 4, p. 772-778, 2006.

MIRANDA, M. B. et al. Perfil físico-químico de aguardentes durante envelhecimento em tonéis de carvalho. Ciências e Tecnologia de Alimentos, v. 28, p. 84-89, 2008. Suplemento.

SEBRAE. Diagnostico da cachaça artesanal. Sebrae, 2008.

SIDEL, J. L.; STONE, H.; BLOMMQUIST, J. Use and mensure of sensory evaluatin in research and quality control. Journal of dairy Science, v. 64, n. 11, p. 2296-2302, 1981.

STONE, H.; SIDEL, J. L. Sensory evalution practices. 2. ed. London. Academic Press, 1993. 337 p.

VILELA, F. J. et al. Determinação das composições físico-químicas de cachaças do sul de Minas Gerais e de suas misturas. Ciências e Agrotecnologia, v. 31, n. 4, p. 1089-1094, 2007.
YOKOTA, S. R. C. et al. Análise sensorial descritiva de cachaça de alambique envelhecida por 18 meses em tonéis de madeiras brasileiras. In: SIMPÓSIO LATINO AMERICANO DE CIÊNCIA DE ALIMENTOS, 5., 2003, Campinas. Anais... Campinas, 2003.

YOKOTA, S. R. C. Avaliação sensorial descritiva de cachaça envelhecida entre 18 e 24 meses 4 paineis de julgadores. 2005. $108 \mathrm{f}$. Tese (Doutorado em Ciências e Tecnologia de alimentos)Universidade Federal de Viçosa, Viçosa, 2005.

ZOOK, K. L.; PEARCE, J. H. Quantitative descriptive analysis. In: MOSKOWITZ, H. Applied sensory of foods - volume 1. Florida: CRC Press, 1988. p. 43-71.

WAKELING, I. N.; MACFIE, J. H. Designing consumer trials balaced for first and higher orders of carry-over effect when only a subset of k samples from $t$ may be tested. Food Quality and Preference, v. 6, n. 4, p. 299-308, 1995. 